\title{
Penggunaan Teknik Think Pair Share dan Teknik Index Card Match Dalam Lesson Study Mampu Meningkatkan Hasil Belajar Siswa
}

\author{
Ketut Rosita Dewi ${ }^{1}$, I Kt. Dharsana ${ }^{2}$ \\ ${ }^{1}$ Prodi Pendidikan Guru Sekolah Dasar, Universitas Pendidikan Ganesha \\ ${ }^{2}$ Prodi Bimbingan Konseling, Universitas Pendidikan Ganesha \\ Universitas Pendidikan Ganesha \\ Singaraja, Indonesia \\ e-mail: rosita.dewi7521@gmail.com¹,profdarsana@yahoo.com²
}

\begin{abstract}
Abstark
Penelitian ini bertujuan untuk mengetahui apakah terdapat peningkatan yang signifikan terhadap hasil belajar tematik siswa kelas VA SD, setelah mendapatkan perlakuan berupa teknik think pair share dan teknik index card match melalui lesson sudy dengan kelompok siswa yang dibelajarkan menggunakan teknik konvensional. Penelitian ini menggunakan jenis penelitian quasi eksperimen dengan rancangan penelitian yang digunakan adalah Randomized Control Trials (RCTs). Adapun populasi pada penelitian ini adalah seluruh siswa kelas VA SD. Pemilihan siswa pada kelompok eksperimen dan kontrol dilakukan dengan cara random sehingga masing-masing kelompok baik kelompok eksperimen dan kelompok kontrol mendapatkan siswa sebanyak 13 orang. Data hasil belajr tematik siswa dikumpulkan dengan menggunakan instrumen tes berbentuk tes pilihan ganda yang berjumla 30 butir soal. Analisis data menggunakan uji-t dengan rumus Levenes Test. Rata-rata hasil belajar tematik siswa pada kelompok eksperimen yang dibelajarkan menggunakan teknik think pair share dan teknik index card match melalui lesson study lebih besar dibandingkan kelompok siswa yang dibelajarkan menggunakan pembelajaran konvensional $(22,85>18,62)$. Berdasarkan hasil analisis data uji hipotesis menggunakan SPSS 22.00 pada tabel keputusan pada nilai Sig (2-tailed) di peroleh nilai 0,009 yang artinya nilai signifikansi $(2$-tailed $)<0,05$. Ini berarti terdapat perbedaan yang signifikan pada hasil belajar tematik antara kelompok siswa yang dibelajarkan dengan teknik think pair share dan teknik index card match melalui lesson study dengan kelompok siswa yang mengikuti pembelajaran konvensional. Dapat disimpulkan bahwa teknik think pair share dan teknik index card match melalui lesson study berpengaruh terhadap hasil belajar tematik siswa kelas VA di SD.
\end{abstract}

Kata Kunci: TPS, ICM, Lesson Study

\begin{abstract}
This study aims to determine whether there is a significant increase in the thematic learning outcomes of VA grade students at SD, after receiving treatment in the form of think pair share and index card match techniques through lesson lessons with groups of students who are taught using conventional techniques. This study uses a quasi-experimental type of research with the research design used is Randomized Control Trials (RCTs). The population in this study were all students of class VA SDN 1 Baktiseraga. The selection of students in the experimental and control groups was done randomly so that each group both the experimental group and the control group got as many as 13 students. Data on students' thematic learning results was collected using a multiple choice test instrument with 30 items. Data analysis using t-test with Levenes Test formula. The average thematic learning outcomes of students in the experimental group who were taught using think pair share and index card match techniques through lesson study were greater than the group of students who were taught using conventional learning (22.85> 18.62). Based on the analysis of hypotheses test data using SPSS 22.00
\end{abstract}


on the decision table on the Sig (2-tailed) value obtained 0.009 value which means the significance value (2-tailed) $<0.05$. This means that there are significant differences in the thematic learning outcomes between groups of students who are taught with think pair share techniques and index card match techniques through lesson study with groups of students who take conventional learning. It can be concluded that the think pair share technique and index card match technique through lesson study have an effect on the thematic learning outcomes of VA class students at SD.

\section{Keywords: TPS, ICM, Lesson Study}

\section{Pendahuluan}

Berbicara tentang pendidikan tentu saja tidak akan pernah ada habisnya. Seperti yang kita ketahui pendidikan di Indonesia telah mengalami banyak perubahan dan penyempurnaan. Salah satu cara dan upaya pemerintah Indonesia untuk menyempurnakan pendidikan adalah dengan melaksanakan revolusi dan pergantian pada kurikulum yang digunakan dalam dunia pendidikan. Pergantian kurikulum di Indonesia telah terjadi sebanyak $11 \mathrm{kali}$, dan saat ini kurikulum yang digunakan pada dunia pendidikan yaitu Kurikulum 2013(Fitriani, Putri, \& Khoiriyah, 2020). Pergantian dan penyempurnaan kurikulum diharapkan mampu meningkatkan mutu dan kualitas pendidikan khususnya pendidikan untuk anak sekolah dasar. Kebijakan pemerintah yang mewajibkan masyarakatnya agar mendapatkan pendidikan wajib selama 12 tahun tenyata belum mampu mengatasi permasalahan-permasalahan yang terjadi di negeri ini (Mirnasulistyawati, Armelia, 2013).

Permasalahan pendidikan di Indonesia sangatlah banyak, mulai dari permasalahan yang diakibatkan oleh siswa, hingga yang disebabkan oleh tenaga pendidik (guru). Pergantian kurikulum ternyata bukanlah cara yang tepat untuk mejadikan pendidikan di Indonesia menjadi lebih baik. Terlebih dengan adanya kurikulum 2013 pada jenjang sekolah dasar, mengakibatkan pelajaran yang didapatkan siswa menjadi lebih sedikt, serta pemahaman siswa mengenai pelajaran yang didapatkannya sangatlah kurang. Pembelajaran berbasis tema tidaklah tepat jika diterapkan untuk anak sekolah dasar. Hall tersebut menjadi tidak tepat karena, seharusnya pendidikan di Seklah Dasar (SD) mampu memberikan pemahaman yang sangat kuat bagi siswanya, tetapi dengan adanya perubahan kurikulum dalam dunia pendidikan menjadikan guru sulit untuk memberikan pemahaman yang kuat dan jelas kepada siswa dikarenakan pembelajaran pada kurikulum 2013 dilaksanakan secara tematik terpadu(Rini Kristiantari, 2015). Selain itu kurikulum 2013 menekankan penanaman nilai-nilai moral dan pendidikan karakter pada materi yang akan dibelajarkan kepada siswa. Namun kenyataan dilapangan, penanaman nilai-nilai moral dan pembentukan karakter yang dilaksanakan oleh guru kepada siswa sangat tidak mudah, terlebih dengan adanya perkembangan teknologi dan globalisasi menyebabkan degradasi moral oleh siswa di Indonesia.

Dengan banyaknya permasalahan dalam dunia pendidikan, pemerintah melaksanakan berbagai upaya, seperti mengeluarkan kebijakan tentang pemilihan sekolah menggunakan sistem zonasi. Penggunaan jalur zonasi diharapkan mampu menekan dan mengurangi kesenjangan terutama kesenjangan ekonomi dan bertujuan untuk pemerataan kualitas pendidikan. Selain itu cara mengurangi permasalahan dalam dunia pendidikan adalah dengan mengangkat guru yang berkompeten dalam bidang pendidikan, memberikan pelatihan kompetensi kepada guru-guru, melaksanakan pembelajaran sesuai dengan kemampuan otak siswa, menggunakan teknik, metode dan model pembelajaran guna untuk meningkatkan pemahaman siswa mengenai pembelajaran yang akan diberikan, serta melahirkan pembelajaran yang bersifat inovatif, kreatif, dan guru wajib memiliki kemampuan berinteraksi yang baik dengan siswanya. 
Berdasarkan hasil wawancara, observasi, dan studi dokumen yang di lakukan pada tanggal 14 November 2019 dengan guru wali kelas VA di SD Negeri 1 Baktiseraga, didapatkan hasil data yang menunjukkan bahwa setiap siswa memiliki minat yang berbeda pada setiap mata pelajaran yang disukainya, sehingga hal tersebut berdampak pada hasil belajar yang didapatkan siswa. Hasil wawancara yang dilakukan dengan 26 siswa kelas VA di SD Negeri 1 Baktiseraga didapatkan hasil bahwa sebanyak 8 orang siswa menyukai pelajaran matematika, 1 orang siswa menyukai pelajaran IPA, 3 orang siswa menyukai pelajaran IPS, 1 orang siswa menyukai pelajaran PKn, 6 orang siswa menyukai pelajaran Bahasa Indonesia, 2 orang siswa menyukai pelajaran Bahasa Inggris, dan 1 orang siswa menyukai pelajaran Bahasa Bali. Pada saat melaksanakan wawancara di kelas tersebut, terdapat 3 orang siswa yang tidak hadir, sehingga peneliti tidak mengetahui terkait mata pelajaran yang disukainya.

Sedangkan berdasarkan hasil observasi yang dilakukan di kelas VA khususnya pada mata pelajaran Tematik didapatkan beberapa hal yang memengaruhi rendahnya hasil belajar siswa. Adapun hal-hal yang didapatkan peneliti selama melaksanakan observasi pada kegiatan pembelajaran tersebut adalah 1) rendahnya hasil belajar tematik siswa dikarenakan siswa sulit mengembangkan pemahaman pada saat belajar. Siswa belum mampu mengaitkan apa yang mereka pelajari di kelas dengan kegunaanya dalam kehidupan sehari-harinya. Hal tersebut karena kurangnya niat dan minat siswa untuk membaca. 2) guru sebagai pengajar seharusnya mampu sebagai fasilitator didalam proses pembelajar, sehingga pembelajaran satu arah dapat dihindari. Agar kegiatan pembelajaran yang dilakukan oleh guru dapat berjalan aktif dan efektif, maka guru dapat menerapkan beberapa teknik didalam kegiatan pembelajaran. Penggunaan teknik didalam kegiatan pembelajaran, tentu akan menjadikan siswa menjadi lebih semangat untuk mengikuti kegiatan pembelajaran didalam kelas. Pada umumnya siswa didalam kelas merasa dirinya kurang mampu sehingga iya selalu merasa membutuhkan bantuan dari temannya self succorance. Sefl succorance menurut Dharsana dalam jurnal (Budiarta, Dharsana, \& Suarni, 2018), merupakan suatu kebiasaan yang mengharapkan bantuan orang lain, mencari dukungan, dan memiliki sifat simpati dengan orang lain, sehingga siswa yang memiliki sefl succorance akan susah mencapai suatu keberhasilan. Selain Self succorance (Dharsana, 2013)hal yang dapat mempengaruhi siswa didalam kelas adalah self nurtuarance yang merupakan suatu kebutuhan yang dapat menyenangkan orang lain, membantu orang lain, dan mengobati orang lain karena rasa simpatinya (Dharsana, 2014).

Dilanjutkan dengan pencatatan dokumen terhadap hasil belajar tematik siswa. Berdasarkan hasil pencatatan dokumen yang dilakukan diperoleh data hasil belajar siswa pada mata pelajaran tematik dengan nilai rata-rata Ulangan Tengah Semester (UTS) masih tergolong rendah dan banyak siswa yang belum dapat mencapai kriteria ketuntasan minimal (KKM) yang telah ditetapkan sekolah pada setiap mata pelajarannya. Tingkat keberhasilan seorang guru didalam mendidik diukur dari seberapa banyaknya siswa yang mampu mendapatkan nilai di atas rata-rata. Hal ini berkaitan dengan bagaimana cara guru mengelola kelas khususnya dalam kegiatan pembelajaran. Kelas yang memiliki siswa aktif didalam kegiatan pembelajarannya, akan ditunjukkan dengan banyaknya siswa yang mendapatkan nilai diatas rata-rata. Namun kelas yang siswanya cenderung pasif dan hanya sebagai penerima informasi dari guru, maka akan menyebabkan siswa mendapatkan nilai dibawah rata-rata. Hal tersebut dapat dikarenakan berbagai faktor salah satunya adalah faktor pembelajaran yang didapatkan oleh siswa didalam kelas.

Pembelajaran merupakan usaha sadar dan terencana yang dilakukan oleh pendidik untuk mengkondisikan atau merangsang seseorang agar dapat belajar dengan baik sehingga terjadi perubahan sikap dan tingkah laku siswa dalam jangka 
waktu yang panjang, serta tercapinya tujuan pembelajaran yang diharapkan (Pane \& Dasopang, 2017). Dalam proses pembelajaran, guru harus mampu menciptakan pembelajaran yang berkualitas ,kreatif, dan antusias bagi peserta didik, hal ini tentunya ditentukan oleh cara guru mengajar dan melaksanakan tugas dan fungsinya dengan baik. Salah satu tugas dan fungsi guru dalam proses pembelajaran adalah sebagai fasilitator dan mediator. Guru sebagai fasilitator bertugas memfasilitasi siswa dengan menyediakan fasilitas dalam proses pembelajaran. Sebagai mediator guru hendaknya memiliki pengetahuan dan pemahaman yang cukup tentang media sebagai alat komunikasi untuk mengefektifkan proses pembelajaran. Selain itu guru juga harus memiliki keterampilan memilih dan menggunakan media yang baik dalam proses pembelajaran (Darmadi, 2015). Selain melihat kualitas pembelajaran yng diberikan oleh guru didalam kelas, penurunan hasil belajar siswa dapat juga diihat melalui tes evaluasi yang berupa nilai yang akan diperoleh siswa baik setiap harinya mapupun setiap akhir semester yang nantinya hasil evaluasi tersebut di kalkulasikan oleh guru menjadi sebuah nilai semester yang disebut dengan raport.

Kegiatan evaluasi pada umumnya digunakan oleh guru pada setiap akhir kegiatan pembelajaran untuk menilai pemahaman siswa dengan diberikan tes berupa tes akhir. Evaluasi juga sering dikatakan sebagai suatu proses yang digunakan untuk menentukan sampai sejauh mana tujuan pendidikan dapat dicapai menurut Tyler dalam jurnal (Lazwardi, 2017). Melalui kegiatan evaluasi guru dapat mengetahui seberapa jauh siswa mampu memahami dan menangkap informasi dari setiap kegiatan pembelajaran yang dilakukan oleh guru. Ketika hasil evaluasi siswa menunjukkan nilai dibawah rata-rata maka guru perlu mengkaji ulang terhadap teknik maupun strategi yang digunakannya selama kegiatan pembelajaran, namun jika hasil evaluasi siswa menunjukkan nilai diatas rata-rata maka guru tersebut dinyatakan berhasil menerapkan tenik maupun strategi didalam kegiatan pembelajaran.

Tujuan akhir dari adanya evaluasi dalam setiap kegiatan pembelajaran adalah untuk menjadi alat intropeksi guru terhadap bagaimana cara ia mendidik dan mentransfer ilmu kepada siswa. Sehingga jika banyak siswa yang mampu mendapatkan nilai diatas rata-rata maka disanalah pembelajaran dikatakan berhasil. Namun jika sebaliknya masih banyak siswa yang belum mampu mendapatkan hasil diatas rata-rata maka guru harus mengkaji ulang bagaimana proses pembelajaran yang efektif bagi siswa.

Pembelajaran dapat dikatakan efektif ketika terjadi komunikasi dua arah antara guru dan siswa yang menjadikan suasa kelas menjadi aktif dan pembelajaran menjadi menyenangkan bagi siswa. Pembelajaran yang efektif adalah "proses pembelajaran yang mampu memberikan nilai tambahan atau ingormasi baru bagi siswa Muthith (2008:6) dalam jurnal (Diani, Soewarno, \& Mislinawati, 2017). Komunikasi dua arah antara guru dan siswa, sangat penting digunakan pada kegitan pembelajaran yang bersifat terpadu. Pada kurikulum 2013 yang digunakan di berbagai jenjang pendidikan di Indonesia, menekankan guru hanya sebagai fasilitator, dan motivator bagi siswa bukan sebagai pengajar. "Mengajar adalah membimbing siswa agar mengalami proses belajar", Slameto (2003:92) dalam jurnal (Diani et al., 2017).

Teknik sangat penting untuk dikuasai oleh seorang guru, karena dengan menguasai teknik tertentu dan diterapkan dalam kegiatan pembelajaran maka akan menghasilkan hasil belajar yang baik bagi siswa. Hasil belajar merupakan hasil dari suatu interaksi tindak belajar dan tindak mengajar Mudjiono dan Dimyati dalam (Lefudin, 2017:13). Selain penggunaan teknik didalam kegiatan mengajar yang dapat menunjang keberhasilan suatu proses pembelajaran, teori belajar juga penting diperhatikan oleh seorang guru didalam kesiapannya memberikan pengetahuan kepada siswa. Salah satu teori belajar yang dapat digunakan guru pada kurikulum 2013 ini adalah teori belajar konstruktivistik. Teori konstruktivistik menyatakan siswa harus menemukan sendiri dan menstranformasikan infromasi kompleks, mengecek 
informasi baru dengan aturan-aturan lama, dan merevisinya apakah aturan-aturan itu tidak sesuai lagi. Piaget dalam (Lefudin, 2017:99), menyatakan bahwa pengetahuan seseorang adalah bentukan (bentuan) orang itu sendiri. Teknik, model serta strategi yang digunakan guru untuk mengajar didalam kelas, sebenarnya terlahir dari beberapa teori belajar.

Teori belajar konstruktivistik memiliki ciri pembelajaran yang bersifat membangun serta mengajak siswa untuk mampu mengkonstruksikan pengetahuan yang didapatkannya melalui berbagai sumber. Terdapat beberapa teknik yang dilahirkan dari teori konstruktivistik diantaranya yaitu teknik think pair share dan teknik index card match. Kedua teknik ini dapat digunakan guru untuk meningkatkan keaktifan, kerjasasama, tanggung jawab, serta hasil belajar siswa. Penerapan penggunaan kedua teknik ini, sama-sama membagi siswa kedalam beberapa kelompok kecil, yang terdiri dari 2-4 orang siswa. Rangkaian pembelajaran secara kelompok akan mengantarkan tujuan pembelajaran akan tercapai, kelompok dapat diartikan dua orang individu atau lebih yang berinteraksi melalui tatap muka serta tiap individu sadar dirinya merupakan bagian dari kelompok dan menimbulkan rasa saling ketergatungan secara positif yang digunakan untuk mencapai tujuan (Putra, dkk., 2015). Guna meningkatkan kualitas pembelajaran yang diberikan oleh guru kepada siswa, guru dapat melaksanakan suatu kegiatan yang tentu saja dapat meningkatkan kualitas pendidikan di sekolah tersebut. Salah satu cara yang dapat digunakan adalah dengan menerapkan lesson study.

Lesson study merupakan suatu proses bersifat kolaboratif yang dilaksanakan oleh sekelompok guru untuk mengidentifikasi berbagai masalah-masalah dalam pembelajaran, merencanakan perbaikan pembelajaran, seorang guru menyelenggarakan pembelajaran sedangkan guru yang lainnya sebagai pemangat, mengevaluasi serta merevisi materi dan kegiatan pembelajaran, melaksanakan kembali pembelajaran hasil revisi dan evaluasi, menyebarluaskan hasil kegiatan lesson study kepada guru lainnya Sparks dalam (Ali Mahmudi, 2009).

Melalui penerapan teknik think pair share dan teknik index card match melalui lesson study, diharapkan mampu meningakatkan hasil belajar pada siswa kelas VA di SDN 1 Baktiseraga.

\section{Metode}

Penelitian ini tergolong metode penelitian eksperimen degan jenis eksperimen yang digunakan adalah eksperimen semu (Quasi Ekspeimental Desain), dikarenakan unit eksperimennya berupa kelas dan terdapat kelompok kontrol namun tidak dapat berfungsi sepenuhnya untuk mengontrol variabel diluar eksperimen. Dengan rancangan penelitian desain penelitian Randomized Control Trials (RCTs), desain yang paling kuat untuk mengevaluasi yang digunakan untuk menunjukkan bahwa interval yang digunakan benar-benar layak. Dalam Purwoko, dkk (2016:55)Randomized dalam RCTs bermakna subjek penelitian memiliki peluang sama untuk ditempatkan secara acak pada kelompok tindakan kelompok eksperimen serta kelompok kontrol. Istilah control trials bermakna terdapat tindakan lain sebagai kontrol tindakan eksperimen.

Populasi dalam penelitian ini adalah seluruh siswa kelas VA di SDN 1 Baktiseraga yang berjumlah 26 orang siswa, yang kemudian dibagi menjadi 2 yaitu 13 orang siswa pada kelompok eksperimen dan 13 orang siswa pada kelompok kontrol. Data yang dikumpulkan dalam penelitian ini dilakasanakan dengan pengambilan data menggunakan metode tes, dengan jumlah butir soal sebanyak 30 butir.

Data hasil belajar pada ranah kognitif dikerjakan dengan bantuan Microsoft Office Excel 2013. Untuk analisis uji prasyarat yang meliputi uji normalitas, uji homogenitas, uji hipotesis mengunakan uji-t dengan rumus Levene Test. 


\section{Hasil dan Pembahasan}

Berdasarkan hasil perhitungan diperoleh nilai rata-rata hasil belajar tematik kelompok eksperimen dengan teknik think pair share dan teknik index card match adalah 22,85, dengan varians sebesar 15, dan standar deviasi sebesar 3.87. Sedangkan nilai rata-rata hasil belajar tematik pada kelompk kontrol menunjukkan anga yang didapatkan siswa sebesar 19,85, varians menunjukkan angka 13,6 serta standar deviasi menunjukkan anagka 3,69. Berdasarkan data tersebut maka pembelajaran menggunakan teknik think pair share dan teknik index card match melalui lesson study memiliki rata-rata nilai lebih tinggi dibandingkan pembelajaran yang menggunakan teknik dengan metode pembelajaran konvensional. Berikut merupakan gambar grafik hasil perhitungan yang menunjukkan hasil kedua kelompok tersebut.

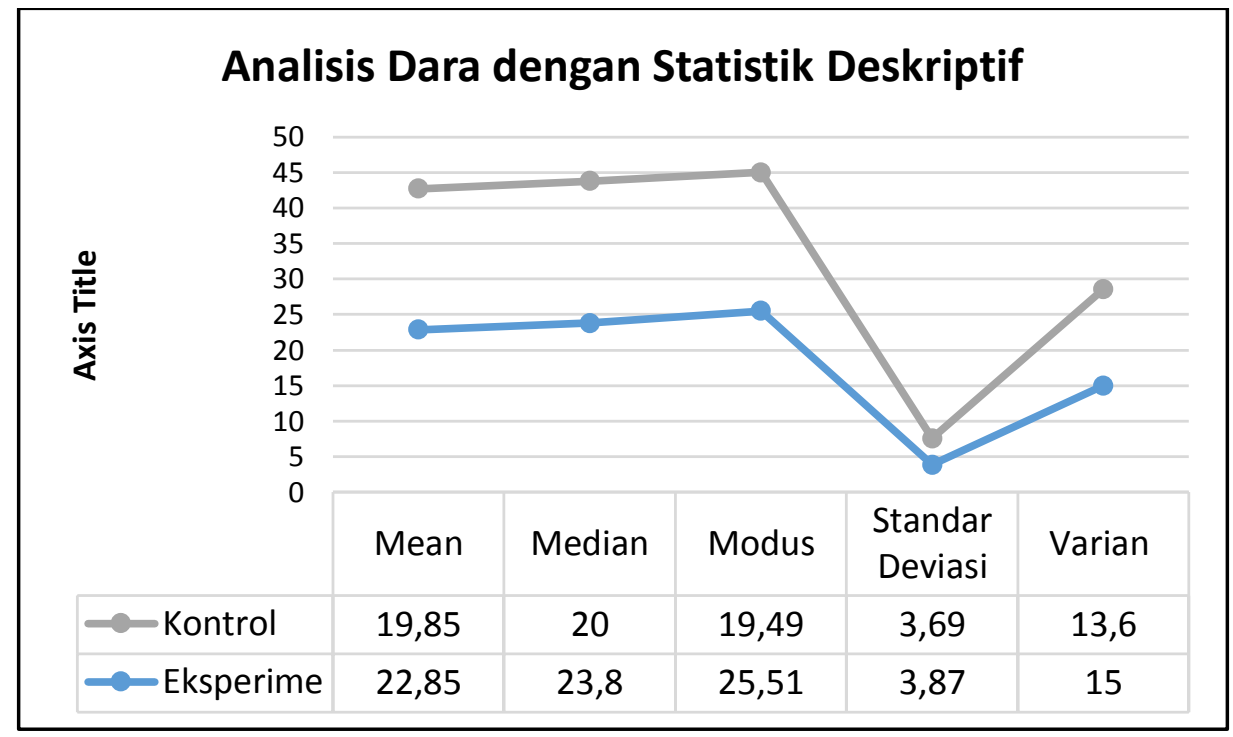

Gambar 1. Grafik Analisis Data dengan Statistik Deskriptif

Sebelum melakukan uji hipotesis, maka terlebih dahulu dilaksanakan uji prasyarat yang meliputi uji normalitas dan uji homogenitas. Uji prasyarat, dilakukan terhadap data skor hasil belajar tematik siswa. Uji nomalitas dilakukan untuk membuktikan bahwa kedua kelompok terebut berdistribusi normal, sedangkan uji homogenitas varians dilakukan untuk mengetahui bahwa kedua kelas tersebut memiliki penguasaan yang relatif sama atau homogen.

Tabel 1. Uji Normalitas menggunakan bantuan SPSS

\begin{tabular}{ccrrr}
\hline \multirow{2}{*}{ Post-test } & \multicolumn{3}{c}{ Shapiro-Wilk } \\
\cline { 2 - 5 } & Think Pair Share & 0,978 & 6 & 0,942 \\
\hline \multirow{2}{*}{$\begin{array}{c}\text { Hasil } \\
\text { Belajar }\end{array}$} & Index Card Match & 0,978 & 7 & 0,949 \\
\cline { 2 - 5 } & Kelompok Kontrol & 0,959 & 13 & 0,736 \\
\hline
\end{tabular}

Hasil perhitungan berdasarkan uji normalitas menggunakan SPSS 22.00 pada kelompok eksperimen yang telah diberikan treatment menggunakan teknik think pair share dan teknik index card match melalui lesson study dapat dilihat pada tabel 
Shapiro-Wilk. Nilai pada Shapiro-Wilks didapat $>0,05$ sehingga data hasil post-test kelompok eksperimen berdistribusi normal.

Setelah melaksanakan uji normalitas, dilanjutkan dengan uji prasyarat yaitu uji homogenitas varians. Hasil uji homogenitas varians menggunakan bantuan SPSS 22.0 menggunakan Levene's Test pada hasil belajar tematik dengan nilai signifikansi $>0,00$ maka data dikatakan bersitribusi homogen, namun apabila nilai signifikansi $<0,05$ maka distribusi data tersebut dikatakan tidak homogen. Hasil uji homogenitas varians data yang telah dianalisis diperoleh hasil belajar pada kelompok eksperimen dan pada kelompok kontrol adalah nilai signifikansi 0,803 sehingga data dinyatakan berdistribusi homogen dikarenakan nilai 0,803 $>0,05$.

Setelah melaksanakan uji normalitas dan uji homogenitas pada data penelitian, kemudian dilanjutkan dengan uji hipotesis dengan menggunakan bantuan SPSS 22.0 untuk menghitung uji -t sampel independent (tidak berkorelasi). Pada uji independen sampel t-test syarat untuk mengambil keputusan adalah dengan melihat 2-tailed, dengan melihat nilai signifikansi (2-tailed) $<0,05$ menunjukkan adanya perbedaan yang signifikansi antara kelompok eksperimen dengan kelompok kontrol. Hal tersebut menunjukkan terhadap pengaruh yang bermakna terhadap perbedaan perlakuan yang diberikan pada kelompok eksperimen.

Tabel 3. Uji Hipotesis

\begin{tabular}{|c|c|c|c|c|c|c|c|c|c|c|}
\hline \multicolumn{11}{|c|}{ Independent Samples Test } \\
\hline & & $\begin{array}{l}\text { Leven } \\
\text { for Eq } \\
\text { Var }\end{array}$ & $\begin{array}{l}\text { Test } \\
\text { lity of } \\
\text { ces }\end{array}$ & \multicolumn{7}{|c|}{ t-test for Equality of Means } \\
\hline & & \multirow[t]{2}{*}{$\mathrm{F}$} & \multirow[t]{2}{*}{ Sig. } & \multirow[t]{2}{*}{$\mathrm{T}$} & \multirow[t]{2}{*}{$\mathrm{df}$} & \multirow[t]{2}{*}{$\begin{array}{l}\text { Sig. (2- } \\
\text { tailed) }\end{array}$} & \multirow[t]{2}{*}{$\begin{array}{c}\text { Mean } \\
\text { Difference }\end{array}$} & \multirow[t]{2}{*}{$\begin{array}{l}\text { Std. Error } \\
\text { Difference }\end{array}$} & \multicolumn{2}{|c|}{$\begin{array}{l}95 \% \text { Confidence } \\
\text { Interval of the } \\
\text { Difference }\end{array}$} \\
\hline & & & & & & & & & Lower & Uppe \\
\hline \multirow{2}{*}{$\begin{array}{c}\text { Hasil Belajar } \\
\text { Tematik }\end{array}$} & $\begin{array}{c}\text { Equal } \\
\text { variances } \\
\text { assumed }\end{array}$ & ,064 & ,803 & 2,838 & 24 & ,009 & 4,231 & 1,491 & 1,154 & 7,308 \\
\hline & $\begin{array}{l}\text { Equal } \\
\text { variances not } \\
\text { assumed }\end{array}$ & & & 2,838 & 23,915 & ,009 & 4,231 & 1,491 & 1,153 & 7,308 \\
\hline
\end{tabular}

Berdasarkan analisis karena menggunakan linear 2 arah maka yang diperhatikan nilai pada sig 2-tailed. Hasil uji-t diperoleh hasil 2-tailed $=0.009$ yang artinya nilai 2tailed $<0,05$ maka $\mathrm{H}_{0}$ ditolak dan $\mathrm{H}_{1}$ diterima. Jika $\mathrm{H}_{0}$ ditolah dan $\mathrm{H}_{1}$ diterima, maka pada data tersebut terdapat pengaruh yang signifikan dari adanya pemberian treatment pada siswa, sehingga dapat diiinterpretasikan bahwa: Terdapat pengaruh yang signifikan pada kelompok eksperimen yang dibelajarkan dengan teknik think pair share dan teknik index card match melalui lesson study dengan kelompok kontrol yang diberikan perlakuan menggunakan teknik yang biasa digunakan oleh guru pada hasill belajar siswa kelas VA di SD Negeri 1 Baktiseraga. Adapun perbandingan hasil pada perhitungan rata-rata antara hasil belajar siswa pada kelompok eksperimen adalah 22,85 lebih besar daripada rata-rata hasil belajar siswa pada kelompok kontrolyang menunjukkan angka 18,62. Hasil temuan nilai rata-rata pada kedua kelompok tersebut, membuktikan bahwa teknik think pair share dan teknik index card match melalui lesson study berpengaruuh terhadap hasil belajar tematik siswa kelas VA di SDN 1 Baktiseraga.

Hasil penelitian yang diperoleh terdapat perbedaan hasil belajar tematik antara siswa pada kelompok eksperimen dan kelompok kontrol disebabkan karena adanya perbedaan penerimaan perlakuan pada proses pembelajaran didalam kelas. Perbedaan penerimaan perlakuan antara siswa dalam proses pembelajaran dapat terjadi karena siswa yang dibelajarkan menggunakan teknik think pair share dan index 
card match (1) penerapan kedua teknik ini didalam kegiatan pembelajaran membuat siswa menjadi lebih aktif didalam kelas, (2) penggunaan teknik dalam kegiatan pembelajaran menjadikan siswa lebih mudah memahami tentang tujuan pembelajaran yang ingin dicapai, (3) siswa menjadi lebih memahami bagaimana cara menghargai pendapat, pemikiran serta pandangan orang lain dan menjaga komunikasi dengan siswa lain, sehingga menjadikan siswa lebih bertanggung jawab, (4) pembelajaran menggunakan berbagai macam teknik menjadikan pembelajaran yang didapatkan oleh siswa lebih bermakna, dan informasi yang ingin disampaikan mudah diserap dan dipahami oleh siswa.

Hasil belajar merupakan sejumlah pengalaman yang diperoleh siswa yang mencangkup ranah kognitif, afektif, dan psikomotor. Belajar tidak hanya digunakan untuk penguasaan konsep teori saja, tetapi juga digunakan untuk penguasaan kebiasaan, persepsi, kesenangan, minat-bakat, keterampilan, dan cita-cita. Menurut Afiyahni, dkk (2019:232) "hasil belajar merupakan suatu pola dari perbuatan, sikap, apresiasi, keterampilan, dan nilai-nilai, hasil belajar yang menjadi objek dalam penilaian di kelas adalah kemampuan baru siswa setelah mengikuti proses belajar". Secara umum, hasil belajar siswa dapat dipengaruhi oleh faktor internal dan faktor eksternal. Sedangkan Mudjiono dan Dimyati dalam (Lefudin, 2017:13), menyatakan bahwa "hasil belajar merupakan hasil dari suatu interaksi tindak belajar dan tindak mengajar".

Terdapat beberapa variasi pembelajaran dengan penggunaan teknik dalam kegiatan pembelajaran yang dapat digunakan oleh guru yaitu teknik Think Pair Share dan teknik Index Card Match kedua teknik ini dapat digunakan oleh guru untuk meningkatkan ke aktifan siswa pada saat kegiatan pembelajaran. Teknik Think Pair Share merupakan teknik yang dipelopori oleh Frang Lyman dengan memberikan variasi susasana pola diskusi kelas dan memberikan kesempatan untuk siswa thinking, pairing, dan sharing(Hamdayana, 2015:210). Sedangkan teknik Index Card Match merupakan teknik yang dapat memupuk kerjasama siswa dalam menjawab pertanyaan dengan encocokkan karti indeks yang ada ditangan mereka. Proses pembelajaran menggunakan teknik ini lebih menarik karena siswa mencari pasangan sambil belajar mengai suatu konsep atau topik dalam suasana yang menyenangkan.

Teknik Think Pair Share merupakan suatu teknik pembelajaran yang memberikan siswa waktu untuk berfikir dan merespok serta saling membantu satu dengan yang lainnya. Teknik ini memperkenalkan ide "waktu berpikir atau waktu tuggu" yang menjadi faktor kuat dalam meningkatkan kemampuan siswa dalam merespon pertanyaan. Kegiatan pembelajaran yang menggunakan teknik Think Pair Share relative mengelompokkan siswa, dan melatih siswa untuk berani berpendapat dan menghargai pendapat temannya (Astuti, 2017) Sedangkan menurut (Istarani 2011:214) dalam (Zandra, Marsis, \& Amrina, 2015), bahwa teknik Index Card Match cukup menyangkan digunakan untuk mengulang materi pembelajaran yang telah diberikan sebelumnya.

Selain menerapkan kedua teknik tersebut, dalam upaya meningkatkan kualitas mutu pembelajaran di kelas, guru dapat melaksanakan suatu prosespembelajaran yang berbasis lesson study. Lesson study pertama kali dikembangkan di Jepang dan dilaksanakan sebagai program pengembangan professionalism guru. Menurut Sparks (1999) dalam (Ali Mahmudi, 2009)Lesson study merupakan suatu proses bersifat kolaboratif yang dilaksanakan oleh sekelompok guru untuk mengidentifikasi berbagai masalah-masalah dalam pembelajaran, merencanakan perbaikan pembelajaran, seorang guru menyelenggarakan pembelajaran sedangkan guru yang lainnya sebagai pemangat, mengevaluasi serta merevisi materi dan kegiatan pembelajaran, melaksanakan kembali pembelajaran hasil revisi dan evaluasi, menyebarluaskan hasil kegiatan lesson study kepada guru lainnya. 
Dalam melaksanakan Lesson Study, guru-guru secara kolaboratif, 1) mempelajari kurikulum, dan merumuskan tujuan pembelajaran dan tujuan pengembangan siswanya (pengembangan kecakapan hidupnya), 2) merancang pembelajaran untuk mencapai tujuan tersebut, 3) melaksanakan dan mengamati suatu research lesson (pembelajaran yang dikaji) untuk kemudian, 4) melakukan refleksi untuk mendiskusikan pembelajaran yang dikaji dan menyempurnakannya, dan merencanakan pembelajaran berikutnya Lewis, Perry, dan Murata (2006) dalam jurnal (Permana, Dibia, \& Dharsana, 2017). Dalam lesson study, dilaksanakan dalam tiga tahapan yaitu ; plan (merencanakan), do (melaksanakan), dan see (merefleksi) yang berkelanjutan. Dengan kata lain lesson study merupakan suatu cara peningkatan mutu pendidikan yang tak pernah berakhir (continuos improvement). Lesson Study merupakan kegiatan yang dapat mendorong terbentuknya sebuah komunitas belajar (learning society) yang secara konsisten dan sistematis melakukan perbaikan diri, baik pada tataran individual maupun manajerial. Slamet Mulyana (2007) dalam jurnal (Ariadi, Dharsana, \& Sudana, 2017) memberikan rumusan tentang Lesson Study sebagai salah satu model pembinaan profesi pendidik melalui pengkajian pembelajaran secara kolaboratif dan berkelanjutan berlandaskan pada prinsip-psrinsip kolegalitas dan mutual learning untuk membangun komunitas belajar.

Pada umumnya lesson study digunakan oleh guru untuk mengevaluasi suatu kurikulum, proses pembelajaran, hasil belajar, maupun sikap siswa selama kegiatan pembelajaran sehingga dengan adanya lesson study memberikan cerminan terhadap guru tentang bagaimana cara mengelola kelas yang efektif dan yang dapat menjadikan siswa menjadi aktif serta pendidikan yang didapatkan siswa lebih bermutu.

Berdasarkan uraian tersebut, maka penelitian ini difokuskan pada penelitian tentang efektivitas teori konstruktivistik dengan teknik think pair share dan teknik index card match melalui lesson study untuk meningkatkan hasil belajar siswa.

\section{Simpulan dan Saran}

Berdasarkan hasil penelitian yang dilaksanakan maka dapat ditarik kesimpuan bahwa terdapat perbedaan yang signifikan pada hasil belajar tematik siswa kelas VA di SDN 1 Baktiseraga antara kelompok eksperimen yang dibelajarkan dengan menggunakan teknik think pair share dan teknik index card match melalui lesson study dengan kelompok yang dibelajarkan dengan model pembelajaran konvensional. Hal ini didukung dengan hasil perhitungan menggunakan SPSS 22.00 yang menyatakan bahwa hasil uji-t diperoleh hasil 2-tailed $=0.009$ yang artinya nilai 2-tailed $<0,05$ maka $\mathrm{H}_{0}$ ditolak dan $\mathrm{H}_{1}$ diterima. Jika $\mathrm{H}_{0}$ ditolak dan $\mathrm{H}_{1}$ diterima, maka pada data tersebut terdapat pengaruh yang signifikan dari adanya pemberian treatment pada siswa, sehingga dapat diiinterpretasikan bahwa: Terdapat pengaruh yang signifikan pada kelompok eksperimen yang dibelajarkan dengan teknik think pair share dan teknik index card match melalui lesson study dengan kelompok kontrol yang diberikan perlakuan menggunakan teknik yang biasa digunakan oleh guru pada hasill belajar siswa kelas VA di SD Negeri 1 Baktiseraga.

Dengan demikian, teknik think pair share dan teknik index card match melalui lesson study berpengaruh terhadap hasil belajar tematik siswa di kelas VA SDN 1 Baktiseraga. Hasil penelitian, pembahasan serta kesimpulan, maka adapun saran yang dapat penelitia ajukan adalah sebagai berikut: 1) teknik think pair share dan teknik index card match melalui lesson study sebaiknya dikembangkan dan dilaksanakan dalam kegiatan pembelajaran di sekolah agar proses pembelajaran lebih berkualitas dan hasil belajar siswa lebih optimal. 2) Dalam pembelajaran di kelas khususnya pembelajaran Tematik, hendaknya dikembangkan dengan menggunakan teknik think pair share dan teknik index card match. Kedua teknik tersebut memiliki keunggulan yaitu mengajak siswa untuk berani berbicara, lebih aktif, belajar menghargai pendapat dan mengemukakan pendapat serta menjadikan pembelajaran lebih bermakna, 3) 
Sebagai bahan pertimbangan khususnya bagi pemerintah dalam meningkatkan dan menilai profesionalisme seorang guru terkait pengembangan pembelajaran, pembekalan, dan pelatihan penerapan teknik pembelajaran khusunya pada teknik think pair share dan teknik index card match melalui lesson study yang telah terbukti mampu membawa perubahan yang bersifat signifikan pada hasil belajar siswa, serta hal tersebut dapat menambah wawasan seorang guru terkait teknik, strategi maupun model-model pemebalajaran yang bersifat inovatif, 4) Sekolah sebagai lembaga penyelenggara pendidikan yang utama, sebaiknya mampu menyediakan fasilitas yang tentu saja dapat menunjang kegiatan pembelajaran, yang nantinya dapat membanttu terlaksananya kegiatan dan proses pembelajaran yang bersifat inovatif dan kreatif, sehingga nantinya hal tersebut akan melahirkan lulusan yang berkualitas dan akan membawa dampak yang baik khususnya pada hasil belajar siswa.

\section{Daftar Rujukan}

Afiyahni, F. D., Huda, C., \& Listyarini, I. (2019). Keefektifan Model Pembelajaran Kooperatif Think Pair and Share Berbantu Media Diorama Terhadap Hasil Belajar Tematik Integratif. Mimbar PGSD, 7, 230-236.

Ali Mahmudi. (2009). Mengembangkan Kompetensi Guru Melalui Lesson Study. Jurnal Forum Kependidikan, 28(2), 84-89.

Ariadi, I. K. G. S., Dharsana, I. K., \& Sudana, D. N. (2017). Pengaruh Model Pembelajaran Pbl Untuk Meningkatkan Hasil Belajar Ipa Melalui Lesson Study Sd Kelas V. MIMBAR PGSD Undiksha, 5(3). https://doi.org/10.23887/jjpgsd.v5i3.12063

Astuti, D. (2017). Model Pembelajaran Think Pair Share (TPS) Untuk Meningkatan Prestasi Belajar Mata Pelajaran IPS Kelas I. Briliant: Jurnal Riset Dan Konseptual, 2(3), 328. https://doi.org/10.28926/briliant.v2i3.71

Budiarta, I. K. R. T., Dharsana, I. K., \& Suarni, N. K. (2018). Efektivitas Konseling Behavioral dengan Teknik Modeling untuk Meningkatkan Self Succorance Melalui Lesson Study Siswa Kelas VIII . 4 SMP Negeri 2 Singaraja. Bisma The Journal of Counseling, 2(2), 64-69. https://doi.org/10.24036/XXXXXXXXXX-X

Darmadi, H. (2015). Tugas, Peran, Kompetensi, Dan Tanggung Jawab Menjadi Guru Profesional. Jurnal Edukasi, 13(2), 161-174.

Dharsana, I. K. (2013). Teori-teori konseling, Singaraja: Universitas Pendidikan Ganesha.

Dharsana, I. K. (2014). Model-Model Toeri, Teknik, Skill Bimbingan Konseling. Singaraja: Universitas Pendidikan Ganesha.

Diani, A., Soewarno, \& Mislinawati. (2017). Pengaruh Pengelolaan Kelas Tehadap Pembelajaran Efektif di Kelas V SD Negeri 50 Banda Aceh. 2, 133-141.

Fitriani, D., Putri, W. S., \& Khoiriyah, Z. H. (2020). Implementasi Pengembangan Kurikulum 2013 dalam Meningkatkan Mutu Pengetahuan, Sikap, dan Keterampilan Siswa. Jurnal Manajemen Pendidikan Islam, 3(1), 29-43. https://doi.org/10.30868/im.v3i01.649

Hamdayana, J. (2015). Model dan Metode Pembelajaran Kreatif dan Berkarakter (1st ed.). Ghalia Indonesia.

Lazwardi, D. (2017). Implementasi Evaluasi Program Pendidikan Di Tingkat Sekolah Dasar Dan Menengah. Kependidikan Islam, 7(2), 67-79.

Lefudin. (2017). Belajar dan Pembelajaran Dilengkapi dengan Model Pembelajaran, Strategi Pembelajaran, Pendekatan Pembelajaran dan Metode Pembelajaran (ke 2; C. M. S. Herlambang Rahmadhani, ed.). Retrieved from https://books.google.co.id/books?id=adwwDwAAQBAJ\&printsec=frontcover\&hl=i $\mathrm{d} \# \mathrm{v}=$ onepage \& $\mathrm{q} \& \mathrm{f}=\mathrm{false}$

Mirnasulistyawati, Armelia, A. (2013). Analisis Penerapan Kurikulum 2013 Dalam Meningkatkan Kualitas Pembelajaran. 
Pane, A., \& Darwis Dasopang, M. (2017). Belajar Dan Pembelajaran. FITRAH:Jurnal Kajian IImu-IImu Keislaman, 3(2), 333-352. https://doi.org/10.24952/fitrah.v3i2.945

Permana, I. P. B. A., Dibia, I. K., \& Dharsana, I. K. (2017). Pengaruh Model Pembelajaran Pbl Untuk Meningkatkan Hasil Belajar Ipa Melalui Lesson Study Sd Kelas V. Mimbar PGSD Undiksha, 5(3), 1-11. https://doi.org/10.23887/jjpgsd.v5i3.12063

Purwoko, B., Prawitasari, J. E., Atmoko, A., \& Handarini, D. M. (2016). Keefektifan Konseling Resolusi Konflik untuk Mengatasi Konflik Interpersonal pada Siswa Sekolah Menengah Atas. Jurnal Pendidikan Humaniora, 4(1), 53-63.

Putra, P. A. D., Sudarma, I. K., \& Tegeh, I. M. (2015). Pengaruh Model Pembelajaran Kooperatif Tipe Gl (Group Investigation) Berbantuan Multimedia Interaktif Terhadap Hasil Belajar IPA. E-Journal Edutech Universitas Pendidikan Ganesha, $3(1)$.

Rini Kristiantari, M. (2015). Analisis Kesiapan Guru Sekolah Dasar dalam Mengimplementasikan Pembelajaran Tematik Integratif Menyongsong Kurikulum 2013. JPI (Jurnal Pendidikan Indonesia), 3(2), 460-470. https://doi.org/10.23887/jpi-undiksha.v3i2.4462

Zandra, W., Marsis, \& Amrina, Z. (2015). Pengaruh Model Pembelajaran Index Card Match Terhadap Hasil Belajar Siswa Pada Pembelajaran Bahasa Indonesia Kelas IV Di SD Negeri 11 Rawang Kabupaten Pesisir Selatan. A Case Approach to Perioperative Drug-Drug Interactions, 123-128. https://doi.org/10.1007/978-14614-7495-1_23 